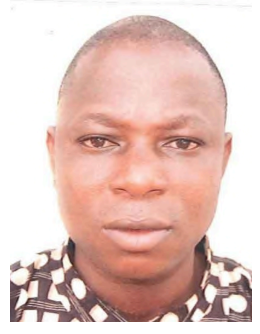

\title{
ENVIRONMENTAL POLLUTION: THE RISE OF MILITARISM AND TERRORISM IN THE NIGER DELTA OF NIGERIA
}

\author{
Christian Madubuko \\ Peace and Conflict Studies \\ University of New England
}

\begin{abstract}
Oil was discovered in large quantities in Nigeria in 1956 and exploration began in the same year. Before oil, agriculture and fishing had assured the Niger Delta people of a bright future. Since 1956, oil has been extracted from the Niger Delta with destructive consequences on the environment, bringing about environmental degradation and destruction of the people's primary means of livelihood. Land and water were badly polluted, and the health of the people affected because of leaks from oil pipelines, gas flaring and acid rains. Several petitions and non-violent protests by Delta communities, women and youth against environmental destruction failed to receive attention. Rather, opposition to peaceful protests earned the people military invasions of their communities, clampdowns and jailings. The rise of militarism and terrorism in the Niger Delta was the result of the Federal Government and Oil Companies' clampdown on non-violent protests for environmental justice in the Niger Delta. This paper discusses the history of oil exploration in the Niger Delta, oil laws, effects of oil exploration in the region, and the rise of militants and terrorists in the area. The paper uses the term, 'environmental justice' to denote unfair treatment and destruction of the Delta environment resulting from oil exploration, non-implementation and enforcement of environmental laws and regulations, and abuse of human rights.
\end{abstract}

The paper suggests solutions for peace in the Niger Delta.

\section{The context}

The Niger Delta is a vast swamp region. ${ }^{1}$ The Delta is Nigeria's richest ecological region, and the largest mangrove ecozone in Africa. ${ }^{2}$ Principally, the Niger Delta refers to a geographical area covering ten Nigerian States: Abia, Akwa-Ibom, Anambra, ${ }^{3}$ Bayelsa, Cross River, Delta, Edo, Imo, Ondo and Rivers. ${ }^{4}$ The region is inhabited by minority ethnic groups of Ijaw, Urhobo, Efik, Ibibio, Ogoni, Itsekiri, Edo, Yoruba and Igbo, with a population of 32 million people. ${ }^{5}$ Apart from the Igbo and Yoruba, these groups are ethnic minorities in the context of the ethnic composition of Nigeria living within the creek areas of the River Niger. The region has been rated the third largest wetland in the world, covering an estimated area of $70000 \mathrm{~km}^{2}{ }^{6}$ The Niger Delta is made up of a large number of rivers, streams, rivulets, lagoons, creeks and estuaries. Although many political interest groups have made distorted claims about the ethnic and demographic composition of the Niger Delta population, history shows that, originally, the region was principally inhabited by a number of minority ethnic groups. ${ }^{7}$

\footnotetext{
1 John Campbell, Nigeria: Dancing on the Brink (Maryland: Rowmand and Littlefield, 2011) 63.

2 Ibid.

3 Oil was discovered in Anambra state by Shell-BP in the 1970s. The Federal Government of Nigeria kept this oil in strategic reserve. In November 2012, the President of Nigeria, Goodluck Ebele Jonathan, commissioned the Anambra oil reserves with the Orient Petroleum Company to begin exploration in 2013. The President declared Anambra as being included in the Niger Delta, bringing the number of oil producing states in Nigeria to ten.

4 Amnesty International, Petroleum, Pollution and Poverty in the Nigher Delta (Amnesty International Publications, 2009) 9.

5 Okechukwu Ibeanu, 'Civil Society and Conflict Management in the Niger Delta' (CLEEN Foundation Monograph Series (2), 2006) 13.

6 Solomon Azaiki, Inequalities in Nigerian Politics (Yenogoa, Bayelsa: Treasure Communications, 2007) 39; see also Campbell, above n 1, 63.

7 Bernard Umoh, 'The Nigerian Oil Industry and Ethnic Militias in Niger Delta' (2005) 5(2) Journal of Environmental Studies 6.
} 


\section{Theoretical discourse}

In the Niger Delta, greed and grievance have played significant roles in the conflict. Research points to greed as the primary contributor to conflict in the region. This school of thought points to Nigeria's dependence on the primary commodity export, oil. According to Mac Ginty, ${ }^{8}$ violence is one of the characteristics of a state whose primary source of income depends on oil. In the attempt to protect its interest by all parties involved, violence becomes the rational means of supporting oneself. Fearen ${ }^{9}$ argues that dependency on a primary export is usually associated with weak states and one reason for this is that weak states lack the incentives to develop administrative capacity because of high revenue, which encourages high-levels of corruption in the system. In line with this argument, a state with centralised government, such as Nigeria, often has weak institutions and when money is transferred, corruption and poor implementation prevail and the state is discredited.

The impact of a primary export commodity is of significance to the Delta region conflict because of Nigeria's dependence on the export of crude oil as means of its income. In the quest to maximise profit, the Nigerian government and oil companies use all means to continue exploration of oil without considering the effects on the environment, which is being destroyed, with negative consequences for the Delta communities. Englebert and Ron ${ }^{10}$ argue that the acquisition of oil resources provides one of the only ways to obtain currency and governments will build forces against possible agitation. In the Delta, government forces have been stationed around oil companies to protect oil installations and prevent disruption of oil exploration in the region.

Collier and Hoeffler ${ }^{11}$ argue that a country is at 'peak danger' when primary export commodities comprise 33 per cent of the total GDP. To Watts, ${ }^{12}$ when primary export commodities make up 26 per cent of the GDP, looting through resource predation and extortion are much more likely to occur. Nigeria, with the oil sector accounting for the bulk of its export earnings, is highly vulnerable to resource conflict, especially in the Niger Delta where the majority of its oil is extracted.

Income level is another greed-based factor that is responsible for conflict in the Niger Delta. Collier and Hoeffler ${ }^{13}$ explained that 'rebellion occurs where foregone income is unusually low'. In Nigeria, more than 100 million out of 140 million people of the country live below the poverty line and on less than $\$ 1$ a day, ${ }^{14}$, enduring high-levels of unemployment, poverty and social wants. In this situation, the potential for joining insurgent or militant groups is high. People in this condition make rational choices between engaging in productive labour (if any ever exist) and joining insurgent or militant forces. The rise in poverty and inequality coincides with the discovery and export of oil in Nigeria. The effect oil has had on income, unemployment and poverty helped to create conditions susceptible to violent conflict in the Niger Delta.

The fact of unmet basic human needs provides a compelling explanation for the existence of conflict in the Delta. Human Needs theory assumes that all humans have basic needs, which they strive to achieve, and that the denial of these needs by other groups or individuals has adverse negative effects on people, thereby resulting in conflict. ${ }^{15}$ Needs theorists such as Abraham Maslow and John Burton argue that the deprivation of basic human needs in societies result in human negative responses against those believed to be working against the realisation of the needs. Burton ${ }^{16}$ lists response, stimulation, security, recognition, distributive justice, need to appear rational and develop rationality, need for a sense of control, shelter and need for role defence as some of the basic needs in society which, if denied, can result in crisis. He identified a link between frustrations, which forces humans into acts of aggression, and the need on the

${ }^{8}$ Roger Mac Ginty, No War, No Peace (Palgrave Macmillan, 2008) 70.

9 J Fearen, 'Primary Commodity Exports and Civil War' (2005) Journal of Conflict Resolution <http://www.jcr.sagepub.com/cgi>.

${ }^{10}$ P Englebert and J Ron, 'Primary Commodity and War' (2004) Comparative Politics

<http://www.jstor.org/stable/4150124>.

${ }^{11}$ C Collier and A Hoeffler, 'Greed and Grievance in Civil War' (2004) 56(4), Oxford Economic Papers

<http://www.oep.oxfordjournals.org/content/56/41563.full.pdf/html>.

${ }^{12}$ Michael Watts, 'Oil Development and the Politics of the Bottom Billion' 24(article 11) Macalester International <http://digitalcommons.macalester.edu/macintl/vol24/iss1/11>

${ }^{13}$ Collier and Hoeffler, above $\mathrm{n} 11,569$

${ }^{14}$ Kate Higgins, 'Regional Inequality and the Niger Delta' (Policy Briefing No. 5, World Development Report, 2009) <http://www.odi.org.uk/resources/download/2507.pdf>

${ }^{15}$ World Bank, Nigeria at a Glance, <http://davdata.worldbank.org/AAG/nga_aag.pdf>.

${ }^{16}$ John Burton, Deviance, Terrorism and War: The Process of Solving Unsolved Social and Political Problems (Macmillan, 1979) 72 . 
part of such people to satisfy their basic needs. According to Burton, individuals cannot be taught to accept practices that destroy their identity and other goals that are attached to their needs and, because of this, they are forced to react against the factors, groups and institutions that they see as being responsible for threatening such needs. No matter how much a political or social system tries to frustrate or suppress these needs, it will either fail or cause far more damage in the long run. Max-Neef ${ }^{17}$ believes that the tension between deprivation and potential are the main issues addressed by human needs theory because, when important needs are not sufficiently satisfied, economic and political problems will continue to grow. Although needs scholars identify a wide range of human needs, some of which they consider to be basic human needs, they agree on the fact that the frustration of these needs hampers the actualisation of the potentials of groups and individuals, subsequently leading to conflict. There is also near consensus among authors that to resolve a conflict situation, or to prevent it from occurring, the needs have to be met with appropriate satisfiers - those things that were denied them in the first instance. ${ }^{18}$

From the point of view of the Delta people, the Nigerian government and the oil companies' inability to meet the needs and aspirations of the region's population are the points of reference in the continued conflict in the Niger Delta; there continues to be a marginalisation of people, and deliberate government economic and social exclusion of the Delta people that prevents them from gaining a share of oil revenues. Ifeka ${ }^{19}$ argues that in Ogoniland alone, government extracted $\$ 30$ billion in profits from the natural resources of the area while 'whole communities (are) pining away in poverty and neglect'. Agitation for resource control hinged on the people's belief that under tradition and international property rights, the natural resources that lie beneath the earth rightfully belong to the inhabitants of the area. ${ }^{20}$ The Nigerian government appropriated the ownership of these natural resources in the Delta through military 'decrees and edicts' and other legislations believed to be obnoxious.

\section{The European contact with the Niger Delta and its colonisation}

The Europeans had known the Niger Delta region as a commercial area before 1885. European explorers, merchants and missionaries had good knowledge of the region and its economic importance to Europe, having visited Benin City in the 15th century for commercial reasons. ${ }^{21}$ It was this 15 th century visit and the benefits from it that motivated other European traders, adventurers and missionaries to come to the Niger Delta later in the 19 th century with other economic and political motives. ${ }^{22}$ European countries notably Portugal, Belgium, Great Britain, France and Germany sent their adventurers, explorers and missionaries to the Niger Delta with a view of colonising the region. ${ }^{23}$ These Europeans scrambled among themselves to have a hold on the Niger Delta hinterlands and its lucrative businesses. Threatened, especially by the Dutch and Germans, ${ }^{24}$ who were determined rivals to Britain, Britain did everything within its power to secure its economic and political interests in the Niger Delta. ${ }^{25}$ In 1984, Consul Hewett, a British representative on the Delta embarked on treaty-making voyages with the local communities of the Delta. ${ }^{26}$ These were the famous 'protection' treaties on which Britain based its legal claims to suzerainty over what later became the Niger Coast Protectorate.

As a result of the ongoing competition among Europeans regarding whose authority was supreme in Africa in general, the German Chancellor, Otto Von Bismarck, summoned the European powers who had interests in the Niger Delta - notably Britain, Portugal, Germany, Belgium and France, to a meeting in Berlin, Germany to discuss the future acquisition of territories in Africa. The meeting lasted from November 1884 to February $1885 .{ }^{27}$ Among other things, the Europeans agreed on three modalities of territorial acquisition in Africa:

\footnotetext{
${ }^{17}$ Manfred Max-Neef, 'Development and Human Needs: Latin America Crisis and Perplexity' in Paul Ekins and Manfred Max-Neef (Routlage, 1992).

${ }^{18}$ Falati Ademola, Theories of Social Conflict (unpublished, 2009) 53.

${ }^{19}$ C Ifeka, 'Violence, Market Forces and Militarisation in the Niger Delta' (2008) 31 (99) Review of African Political Economy 147.

20 Ibid 144.

${ }^{21}$ Onwuka Dike, Trade and Politics in the Niger Delta 1830 - 1885 (Oxford: ACLS History e-Book Project, 2008).

22 Dan O Chukwu, An Introduction to Nigerian Political History (Enugu: Rhema Publications, 2005) 34

${ }^{23}$ Dike, above $\mathrm{n} 22,20$.

${ }^{24}$ E J Allagoa, 'Peoples of the Cross River Valley and the Eastern Niger Delta' in Obaro Ikime (ed) Groundwork of Nigerian History (badan: Heinemann Educational Books, 1980) 249.

${ }^{25}$ Obaro I kime, European Resistance in the Niger Delta, (1973) 4(3) Tarikh.

${ }^{26}$ Ibid, 276.

27 Onwuka, above n 22.
} 
1. Any European power that had missionary contact with any African communities should claim the area;

2. Any European nation that had commercial relations with any African nation should lay claim to the region;

3. Any European nation that had signed treaty of protection with any Africa nation should claim the area. $^{28}$

Resulting from this agreement, Britain claimed the Niger Delta, colonised it and later gave it the name Nigeria. $^{29}$

\section{Oil and Niger Delta region}

Oil exploration has a long history in the Niger Delta. The search for oil in the region began in 1903, after the British takeover of the region, by the Nigerian Properties Limited, and the Nigerian and West African Development Syndicate Limited. ${ }^{30}$ Between 1903 and 1905, investigation by geologists Collins and Harrison showed the existence of vast reserves of bitumen and petroleum in the Niger Delta area.

In November 1905, a British businessman, John Simon Bergheim, founded the Nigerian Bitumen Corporation (NBC) and, in 1907, the British government granted a loan of 25,000 British pounds sterling to NBC to expand its oil exploration in the Niger Delta. ${ }^{31}$ Between 1908 and 1912, NBC discovered more oil blocs. However, following the death of Bergheim in $1912^{32}$ NBC ceased operation and was liquidated in $1914 .^{33}$

Before his death, Bergheim had drafted a regulation that would guide oil exploration activities in Nigeria. His draft was modelled on the Trinidad Oil Mining Laws, ${ }^{34}$ and became the basis for the Southern Nigerian Mining Regulation (Oil) Ordinance of 1907, which made exploration and prospecting the prerogative of the British and British-allied companies registered in Britain or British colonies. ${ }^{35}$ Section 15 of the Ordinance specified that members of the directorates of any oil company be only British subjects. ${ }^{36}$ The Ordinance empowered the Governor General to enter into agreements with the Native Authorities over the takeover of both surface and sub-surface mineral rights on their lands without compensation or payment of royalties on oil. ${ }^{37}$ In protesting against the Ordinance, the oil-bearing communities of Eastern Nigeria (Niger Delta) stated that:

If the Ordinance becomes law, or rather when (it) does become law, it will give to the government and the European prospectors the kernel of the oil mining business, leaving to the natives the shell. In other words giving him the doubtful privilege of working to enrich the white man. ${ }^{38}$

The Governor-General and the oil companies rejected the protests and applied military force to enforce the letters of the Ordinance on the people and the environment. ${ }^{39}$ In 1914, the Southern and Northern protectorates were amalgamated to become Nigeria. The colonial Mineral Ordinance was passed in 1914, which formalised state control of oil exploration and prospecting. ${ }^{40}$ The Ordinance did not require the oil companies to obtain permission from any landowners to conduct exploration work on their land. Rather, it guarantees protection for the oil companies from any person or group of persons who might interfere with

28 Ibid.

29 Ibid.

${ }^{30}$ Phia Steyn, Oil Exploration in Colonial Nigeria, C. 1903 - 1958 (University of Stirling, 2006)

<http://dspace.stir.ac.uk/bitstream/1893/2735/1/oil exploration in colonial Nigeria.pdf>.

${ }^{31}$ D K Fieldhouse, Unilever Overseas: The Anatomy of a Multinational 1895-1955 (Croom Helm, 1978$) 98$.

${ }^{32}$ Edgar Wesley Owen, Trek of the Oil Finders: A History of Exploration for Petroleum (Tulsa: American Association of Petroleum Geologists, 1975) 30.

33 'Oil and the Niger Delta', Times International, 16 October 1911, 23; Also Mr Crewe to Sir W Egerton, Governor of Nigeria, 30 August 1909 (Confidential Letter), CSE 8 april - CSP 368/09, Nigerian national Archives, Enugu Branch (NNAE).

${ }^{34}$ Robert Shenton, 'Nigerian Agriculture in Historical Perspective: Development and Crisis, 1900-60' in Michael Watts, (ed), State, Oil and Agriculture in Nigeria (Berkeley: University of California, 1987) 14.

35 Edwin Aney Speed (ed), Laws of the Colony of Southern Nigeria Being the Schedule to the Statute Laws Revision Ordinance (London: Stevens, 1908, Vol II). See also, Shell Petroleum Development Company of Nigeria Limited, The ShellBP Story (Port-Harcourt: Shell-BP, 1965) 6.

${ }^{36}$ Shenton, above n 35, p. 14.

37 'Oil and the Niger Delta, above n 33, 21.

38 Shell Petroleum Development Company of Nigeria Limited, above n 36, 16.

${ }^{39}$ Phia Steyn, above n 31, 15.

40 Ibeanu, above n 5, 18. 
their work. Such person(s) was/were liable, on conviction, to be fined or imprisoned or both. ${ }^{41}$ The Ordinance gave meagre protection rights to the local communities. It offered compensation for the destruction of economic trees and crops by the oil companies in the events of oil exploration at rates determined by the District Officer. ${ }^{42}$ Owing to oil pollution and its effects on the environment in the 1940s, the Niger Delta communities demanded the repeal of the Mineral Oils Ordinance.

In January 1956, Shell/D'Arcy found oil in a commercial quantity at Oloibiri, 72 km west of Port Harcourt (at a depth of $12008 \mathrm{ft}$ ). ${ }^{43}$ Exploitation starting in the early 1958 at 3000 barrels per day. On 8 March 1958, Nigeria exported the first batch of oil (8500 tons of crude oil) to Rotterdam in the Netherlands. ${ }^{44}$ The success of Shell/D'Arcy attracted the attention of other multinational oil companies, such as Exxon Mobil, Total, Elf, Chevron, Conoco Philips and Conoil. Even before the discovery at Oloibiri, the process of opening-up the Nigerian oil industry had begun in 1955 when Shell/D'Arcy granted an oil exploration licence to the Mobil Exploration Company (a division of the Socony - Mobil Oil Company). ${ }^{45}$ The discovery of oil in commercial quantities in Nigeria in 1956 coincided with the 1956 Suez Canal crisis, which encouraged multinational oil companies' interests in the Niger Delta. ${ }^{46}$

In 1959, the departing colonial government passed the Petroleum Profit Tax Ordinance, which provided $50 / 50$ profit sharing between the government and the oil companies. ${ }^{47}$

Legal provisions on payment of compensation for damage caused by oil exploration in the Niger Delta

The Colonial Mineral Oils Ordinance of 1907 laid the foundations for the post-independence Nigerian oil promulgations. ${ }^{48}$ The Ordinance left the monopoly of the oil industry in the hands of the British. It also abrogated the rights of the indigenous peoples of the Niger Delta to their lands and natural resources and laid the foundation for no compensation and payment of royalties on oil to the local people. ${ }^{49}$ After Nigeria's independence in 1960, the post Nigerian oil law became the model for the colonial Mineral Oils Ordinance and provides that, 'all minerals, mineral oils and natural gas' are the property of the federal government. ${ }^{50}$ For instance, the Petroleum Decree Act of 1969, Decree No. 9 of 1971 appropriated oil minerals and other natural resources to the federal government.

The Nigerian Constitution vested general supervisory powers over oil companies' activities in the Minister of Petroleum Resources who may revoke a license under certain conditions, particularly if the companies fail to comply with 'good oilfield practice'. ${ }^{51}$ The decree establishing this fails to define the terms of 'good oilfield practice'. However, the Mineral Oils (Safety) Regulations of 1963 under the Mineral Oils Act (the predecessor to Petroleum Act) provides that good oilfield practice 'shall be considered to be adequately covered by the appropriate current Institute of Petroleum Safety Codes, the American Petroleum Institute Code, or the American Society of Mechanical Engineers Code', binding holistically the oil companies to respect international standards in oil operation in Nigeria. ${ }^{52}$ The oil companies are, therefore, responsible for the actions of independent contractors working on their behalf. ${ }^{53}$ It is the responsibility of oil companies to 'adopt all practicable precautions including the provision of up-to-date equipment' to prevent pollution, and must take 'prompt steps to control and, if possible, end it', should pollution occur. ${ }^{54}$ The Regulation requires oil companies to maintain all installations in good repair and conditions to prevent the, 'escape or avoidable waste of petroleum' and to cause 'as little damage as possible to the surface of the relevant area and to the trees, crops, buildings, structures and other properties thereon' ${ }^{55}$ The Regulation also provides that oil companies must comply with all local planning laws; and should not enter on any area held to be

\footnotetext{
${ }^{41}$ S A Khan, The Political Economy of Oil (Oxford University Press, 1994) 6.

42 Donald Kingdom, The Laws of Nigeria Containing the Ordinances of Nigeria in Force on the $1^{\text {st }}$ Day of January 1923 (Lagos: Government Printer, 1923, Vol 1).

${ }^{43}$ Munro j Forbes, Maritime Enterprise and Empire: William Mackinnon and His Business Network, $1823-1893$ (Woodbridge: Boydell and Brewer, 2003) 132.

${ }^{44}$ Khan, above $\mathrm{n} 42$.

45 S R Pearson, Petroleum and the Nigerian Economy (Stanford University Press, 1970) 33.

${ }^{46} \mathrm{~L}$ H Schctzl, Petroleum in Nigeria (Oxford University Press, 1969) 64.

${ }^{47}$ Ibeanu, above $\mathrm{n} 5,17$.

${ }^{48}$ Victor Ojakorotu and Ayo Whetho, 'Multinational Corporations and Human Rights Abuses: A Case Study of the Movement for the Survival of Ogoni People and ljaw’ (2008) 2 (May) Resistance Studies Magazine.

${ }^{49}$ Colonial Mineral Oils Ordinance, 1907 s 35 (22).

${ }^{50}$ Article 40(3) of the 1979 Constitution; art 42(3) of the 1989 Constitution; art 47(3) of draft 1995 Constitution.

51 Petroleum Act, Cap. 350, Laws of the Federation of Nigeria, Schedule 1, section, 24(1).

${ }_{52}$ Mineral Oils Safety Regulations (Nigeria), reg 7.

53 Petroleum (Drilling and Production) Regulation (Nigeria), reg 15(2).

54 Ibid, reg 25.

55 Ibid, reg 36.
} 
sacred or destroy anything deemed as an object of veneration; they must allow local inhabitants to have access, at their own risk, to roads constructed in their operating areas. ${ }^{56}$

Under the 1978 Land Use Act, all land is vested in the Governor of the State and it is lawful for the Governor 'to revoke a right of occupancy for overriding public interest'. Overriding public interest includes 'the requirement of the land for mining purposes or oil pipelines or for any purpose connected therewith'. ${ }^{57}$ Communities living on the land cannot prevent this from occurring, and there is no provision in the law for consultation.

Provisions within the Oil Pipeline Act of 1956 (as amended, 1965, 2002, 2004) and the Petroleum Act of 1969 empowers the federal government of Nigeria to grant access and use rights in relation to land for the purposes of oil prospecting and mining. Once a company has been granted permit, licence or lease, the state government has to give access to the land. ${ }^{58}$ The local communities are compensated according to a formula that primarily assesses value based on 'surface goods' lost. ${ }^{59}$ The compensation arrangements do not consider the long-term implications of loss of access to critical livelihood resources. Besides, the Land Use Act bars courts from addressing any concerns about the amount or adequacy of compensation paid to people who lose access to their land under the terms of the Act. ${ }^{60}$ Altogether, the constitutional provisions on oil and gas, the Land Use Act, the Oil Pipelines Act and aspects of the oil laws of the Federal Republic of Nigeria has empowered the three tiers of government (federal, state and local governments) to expropriate land for use by the oil industry without due process and adequate compensation to the land owners in clear contravention of its International Human Rights Obligations (IHRO), particularly the right to adequate standard of living. ${ }^{61}$ The provisions of these laws, which significantly undermine communities' security of tenure, also create the legal foundations for oil companies to operate without due regard for the impacts of their operations on human rights. For example, holders of leases and licences and permits to survey under the Petroleum Act, Oil Pipelines Act and subsidiary legislations are entitled to engage in a range of activities - from cutting down trees and other vegetation, to dredging - without any adequate safeguards in terms of the impact of these activities on the environment and its associated livelihoods of the communities. ${ }^{62}$ These laws were made irrespective of the African Charter on Human and Peoples Rights ${ }^{63}$ to which

56 Ibid, regs 17,19 , and 22

${ }^{57}$ Land Use Act (Nigeria), CAP 202 (1990), ss 28 (1) and 28 (2) (c) and 28 (b).

58 Personal interview with one of the senior representatives of the Shell Petroleum Development Corporation in Bayelsa state, Nigeria, 18 May 2013.

59 Under the Land Use Act (Nigeria), once the right of occupancy is revoked for the purposes similar to oil and mining, the landowner is entitled to compensation under the provisions of the relevant mining and oil laws. Section 36 of the Petroleum Act states: "holder of an oil exploration licence, oil prospecting licence or oil mining lease shall, in addition to any liability for compensation to which he may be subject under any other provision of this Act, be liable to pay fair and adequate compensation for the disturbance of surface or other rights to any person who owns or is in lawful occupation of the licensed or leased land'. Section 20 of the Oil Pipelines Act states: 'If a claim is made under subsection (3) of section 6 of this Act, the court shall award such compensation as it considers just in respect of any damage done to any buildings, lion crops or profitable trees by the holder of the permit in the exercise of his rights there under and in addition may award such sum in respect of disturbance (if any) as it may consider just'. In practice, the federal government focuses compensation calculations on the surface goods lost under the headings of crops, economic trees and buildings. Most often, there is no compensation at all and any negative reaction from the land owner(s) could be visited with the full wrath of the government security operatives in the Delta.

${ }^{60}$ Clause 47 (2) of the Oil Pipelines Act 1965 (Nigeria) provides: 'No court shall have jurisdiction to inquire into any question concerning or pertaining to the amount or adequacy of any compensation paid or to be paid under this Act'.

${ }^{61}$ Article 11 of the International Convenient on Economic, Social and Cultural Rights.

62 Section 5 (1) of the Oil Pipelines Act (Nigeria) provides: 'A permit to survey shall entitle the holder, subject to the section 6 of this Act, to enter together with his officers, agents, workmen and other servants and with any necessary equipment or vehicles, on any land upon the route specified in the permit or reasonably close to such route for the following purposes (a) to survey and take levels of the land; (b) to dig and bore into the soil and subsoil; (c) to cut and remove such trees and other vegetation as may impede the purposes specified in this subsection; and (d) to do all other acts necessary to ascertain the suitability of an oil pipeline or ancillary installations, and shall entitle the holder, with such persons, equipment or vehicles as aforesaid to pass over land adjacent to such route to the extent that such may be necessary or convenient for the purpose of obtaining access to land upon the route specified'. Section 11 provides: 'A licence shall entitle the holder, his officers, agents, workmen, servants with any necessary equipment or vehicles, subject to the provisions of section 14,15 and 16 of this Act, to enter upon, take possession of or use a strip of land of a width not exceeding two hundred feet or of such other width or widths as may be specified in the licence and upon the specified in the licence, and thereon thereover or thereunder construct, maintain and operate an oil pipeline and ancillary installations'. A right to object is provided under s 9 of the Act. It states: 'Any person whose land or interest in land may be injuriously affected by the grant of licence may within the period specified for objections lodge verbally or in writing at one of the specified addresses notice of objection stating the interest of the objector and the grounds of objection'.

${ }^{63}$ Article 21 of the African Charter provides that, '(i) All peoples shall freely dispose of their wealth and natural resources. This right shall be exercised in the exclusive interest of the people. In no case shall a people be deprived of it; 
Nigeria is a member. Article 14 of the charter guarantees the rights of individuals and groups to own property. Such rights should not be interfered with unless in the interest of public need or in the general interest of the community and in accordance with the provisions of appropriate laws. The Nigerian state hides under the interest of 'public need' to encroach on the rights of the Delta communities to natural resources through unpopular laws considered by many as obnoxious.

The principal statute governing real property in Nigeria is the 1978 Land Use Act (originally Decree No 6 of 1978), which, as mentioned earlier, vested all lands within a territory in the governor of that state. ${ }^{64}$ The 1979 Nigerian Constitution specifically provides that nothing in the constitution shall invalidate the Land Use Decree. ${ }^{65}$

The Land Use Act provides that if land is acquired for mining purposes, the occupier is entitled to compensation as provided under the Minerals Act or the Mineral Oils Act (now superseded by the Petroleum Act). If compensation is due to a community, it may be paid 'to the community', 'to the chief or leader of the community to be disposed of by him for the benefit of the community', or 'into some fund specified by the Military Governor for the purpose of being utilised or applied for the benefit of the community' ${ }^{66}$ The Petroleum Act (originally Decree No. 51 of 1969), however, makes no provision for compensation to be paid for land acquisition. Section 1 of the Act vested the entire ownership and control of all petroleum in, under or upon any land within the country or beneath its waters in the state. Although the Act requires the holders of oil exploration licenses, oil prospecting licenses or oil mining leases to pay 'fair and adequate compensation for the disturbance of surface or other rights' to the owner or occupier of any land or property, ${ }^{67}$ nothing is due for expropriation of the land itself; thus for properties acquired since the Land Use Act came into effect, rent is paid to the federal government only. ${ }^{68}$ Since oil is federal property, land occupiers are entitled to no royalties for oil extracted from their land.

The Oil Pipelines Act of 1956 (as amended) provides for compensation both in respect of surface rights and in respect of the loss of value of the land affected by a pipeline. ${ }^{69}$ Disputes as to the compensation due may be referred to court, which 'shall award such compensation as it considers just', taking into account not only damage to buildings, crops, and 'economic trees', but also damage caused by negligence or disturbance, and the loss in value of the land or interests in the land. ${ }^{70}$

Oil companies acquire lands for oil operations from the Nigerian government under these laws, which in practice allow the government to expropriate land for the oil industry with no effective due process protec-

(ii) In case of spoilation, the dispossessed people shall have the right to the lawful recovery of its property as well as to an adequate compensation; (iii) The free disposal of wealth and natural resources shall be exercised without prejudice to the obligation of promoting international economic cooperation based on mutual respect, equitable exchange and the principles of international law; (iv) State Parties to the present Charter shall individually and collectively exercise the right to free disposal of their wealth and natural resources with a view to strengthening African Unity and solidarity; (v) State Parties to the present Charter shall undertake to eliminate all forms of foreign exploitation particularly that practised by international monopolies so as to enable their peoples to fully benefit from the advantages derived from their national resources'.

${ }^{64}$ Section 1, Decree No 6 of 1978, Cap 202, Laws of the Federation of Nigeria.

${ }^{65}$ Article 274(5) of the 1979 Constitution. This provision is repeated in art 346(5) of the Draft 1995 Constitution.

${ }^{66}$ The Act also provides for Land Use and Allocation Committees to be appointed by and advise the military governors on the management of the land, and to settle disputes as to compensation to be paid.

${ }^{67}$ Petroleum Ac $t$ (Nigeria), s 36. The Petroleum (Drilling and Production) Regulations, made under the Act, also provide that before entering or occupying any private land, oil companies are required to obtain written permission from the government and pay 'fair and adequate compensation' to the lawful occupiers, presumably in respect of the rights mentioned in the primary legislation. Petroleum (Drilling and Production) Regulations, reg 17(c)(ii).

${ }^{68}$ Before the Land Use Act came into effect, the Public Land Acquisitions (Miscellaneous Provisions) Act 1976 and other laws provided for compensation to be paid in respect of the land acquired itself. See J A Omotola, 'Compensation provisions under the Act' in Essays on the Land Use Act, 1978 (Lagos University Press, 1984) ch 5.

${ }^{69}$ The Act provides: 'The holder of a licence shall pay compensation: (a) to any person whose land or interest in land (whether or not it is land in respect of which the licence has been granted) is injuriously affected by the exercise of the rights conferred by the licence, for any such injurious affection not otherwise made good; and (b) to any person suffering damage by reason of any neglect on the part of the holder or his agents, servants or workmen to protect, maintain or repair any work structure or thing executed under the licence, for any such damage not otherwise made good; and (c) to any person suffering damage (other than on account of his own default or on account of the malicious act of a third person) as a consequence of any breakage or leakage from the pipeline or an ancillary installation, for any such damage not otherwise made good'. Oil Pipelines Act, Cap 338, Laws of the Federation of Nigeria, 1990, s $11(5)$.

${ }^{70}$ Ibid s 20(3): 'In determining the loss in value of the land or interest in land of a claimant the court shall assess the value of the land or the interests injuriously affected at the date immediately before the grant of the licence and shall assess the residual value to the claimant of the same land or interests consequent upon and at the date of the grant of the licence and shall determine the loss suffered by the claimant as the difference between the values so found, if such residual value is a lesser sum.' 
tions for those whose livelihoods may be destroyed by the confiscation of their land. While every government has the right to acquire land for public purposes, those affected should have the right to voice opposition to the acquisition, to challenge it before an impartial court, and to obtain adequate compensation. In practice, the oil companies themselves make the decision as to the land that will be expropriated and the determination of such compensation as will be paid. Since the Land Use Act and the other relevant law provides local communities with very limited rights over land they have traditionally used, both government agencies and private companies are largely able to ignore customary land use rights, in the oil areas as elsewhere. Because the Nigerian government has complete control over land, oil companies find it easy to ignore local concerns and to fail to ensure that local communities are fully consulted. Decisions relating to use of land are completely taken out of the hands of those who have lived on the land and used it for centuries.

In addition, the Petroleum Act does not explicitly refer to spills, but its requirement for oil companies to pay 'fair and adequate compensation for the disturbance of surface or other rights' to the owner or occupier of any land or property affected by exploration or production has been held to apply to oil spills. ${ }^{71}$ There is no statutory definition of fair and adequate compensation, but in the lead case interpreting this provision, Shell Petroleum Development Company v Farah, the Court of Appeal, basing its judgment on English and Nigerian case law, stated that compensation should 'restore the person suffering the damnum (loss) as far as money can do that to the position he was before the damnum (loss) or would have been but for the damnum'. ${ }^{72}$ The Petroleum (Drilling and Production) Regulations, made under the Act, provide only for compensation for interference with fishing rights. ${ }^{73}$

The Federal Environmental Protection Agency Act, in addition to providing for criminal liability for contravention of its provisions, and for spillers to be responsible for the cost of rehabilitating land, states that companies violating its provisions or regulations made under it 'shall be directed to pay compensation for any damage resulting from such breach thereof or to repair and restore the polluted environmental area to an acceptable level as approved by the Agency unless he proves to the satisfaction of the court that: (a) he used due diligence to secure compliance with this Act; and (b) such offence was committed without his knowledge consent or connivance'. ${ }^{74}$

Nigerian case law also incorporates liability for negligence, nuisance, trespass, and the rule in Rylands $v$ Fletcher, an English law case of 1866, which held that anyone bringing onto land, in the course of a 'nonnatural' use of the land, something 'likely to do mischief if it escapes ... is prima facie answerable for all the damage which is the natural consequence of its escape. ${ }^{, 75}$ The Nigerian courts have held that crude oil can (though does not always) fall into this category. The rule provides for strict liability; that is to say, it is not necessary to prove negligence on the part of the person allowing the damaging material to escape, once it has been shown that the use is 'non-natural' and that the material is dangerous or 'mischievous'. However, 'the owner of a dangerous thing is not liable if the thing has escaped through the independent act of a third party and there has been no negligence on his part ... in the absence of a finding that he instigated [the act] or that he ought to have provided against it'. ${ }^{76}$ But most of such occurrences so far in the Delta are attributed to sabotage involving oil-workers.

In cases of sabotage, the Nigerian law provides that, the oil companies do not pay compensation for spills, on the grounds that to pay compensation creates an incentive to damage oil installations and harm the environment. Meanwhile, even if a spill is caused by sabotage, the person carrying out the sabotage is not necessarily the person who suffers the damage. Interviews from my fieldtrips to the Niger Delta in 2013 and 2014 respectively show that 'sabotage is carried out by contractors likely to be paid to clean up the damage

\footnotetext{
${ }^{71}$ Petroleum Act (Nigeria) s 36.

72 [1995] 3 NWLR (pt 382) 148,192. The Farah case arose from a blow out at Shell's Bomu II oil well in Tai/Gokana local government areas in Ogoni in 1970, though the case was not commenced until 1989. Shell has appealed from the Court of Appeal to the Supreme Court.

${ }^{73}$ Regulation 23 states that 'if the licensee or lessee exercises the rights conferred by his licence or lease in such a manner as unreasonably to interfere with the exercise of any fishing rights, he shall pay adequate compensation therefor to any person injured by the exercise of those first-mentioned rights'.

${ }^{74}$ Federal Environmental Protection Agency Act, (Nigerial) s 36.

75 (1866) LR1 Exch 265. 'Oil naturally occurs in the ground, and therefore in its natural state would not come under the rule in Rylands $v$ Fletcher. However, once it has been channelled through pipes or gathered into tanks, its presence is no longer 'natural' and the rule applies. However, the case law on the issue is not entirely consistent'. See J Finine Fekumo, 'Civil Liability for Damage Caused by Oil Pollution' in J A Omotola (ed), Environmental Laws in Nigeria (University of Lagos Press).

${ }^{76}$ SPDC v Chief Graham Otoko and five others [1990] 6 NWLR (p 159), 693, 724.
} 
in connivance with oil workers and community chiefs'. ${ }^{77}$ Human Rights Watch records that a former adviser to a state petroleum minister commented as follows: "It is true that there is a lot of sabotage, but often it is the chiefs who do it. The oil company then settles the chiefs (ie, pays them off) by giving them the contract to clean up, but they tell the youth they have received nothing. Then the youth protest and cause damage and the chiefs get more money. If the government and the oil companies did development projects properly it would not happen'. ${ }^{78}$

Another legal body in the country that provided for compensation for oil spills on the environment is the Environmental Guidelines and Standards for the Petroleum Industry in Nigeria (EGASPIN). Part VIII of EGASPIN deals with oil spills. This section of the regulations provides that, 'A spiller shall be liable for the damage from a spill for which he is responsible. Settlement for damages and compensation shall be determined by direct negotiation between the operator(s) and the landlord(s).' The problem here is, to whom shall compensation be paid and who negotiates with the oil operators since the federal government and oilcommunities both lay claims to ownership of oil? Between the federal government and Niger Delta communities, who is the legitimate owner of oil?

\section{Impacts of oil exploration in the Niger Delta}

Multinational oil companies in the Niger Delta maintain that their oil operations are conducted to the highest environmental standards and the impacts of oil to the environment is minimal. Shell Nigeria claims that the environmental problems in the Niger Delta are not as a result of oil drillings. ${ }^{79}$ But the Environmental Groups (Friends of the Earth) persistently accused the oil companies of double standards for allowing practices in Nigeria that would never be permitted in North America or Europe. ${ }^{80}$ Shell denies the allegation stating that, "the charge of "double standards" is mistaken, because it is based on the notion that there is a single, "absolute environmental standard" ... As long as we continue to improve, varying standards are inevitable'. It adds, 'Higher environmental standards could harm local economies'. ${ }^{81}$ This postulation is inconsistent compared with the effects of oil pollution on the Delta flora and fauna.

The negative impact of oil on Delta communities seriously undermines the Human Rights of the people living in the region. Oil has had dangerous and destructive consequences on the environment of the host oilcommunities in the Niger Delta. Over the years, exploration effects on the environment have been endemic and devastating. Ken Saro-Wiwa described the effects of oil drilling on the Delta environment as 'completely devastated by three decades of reckless oil exploration or ecological warfare by Shell ... An ecological war is highly lethal, the more so as it is unconventional. It is omnicidal in effect. Human life, flora, fauna, the air, fall at its feet, and finally, the land itself dies' ${ }^{82}$ Environmental destruction of the Niger Delta through oil exploration by the oil companies in addition to poverty in the land is the core of the problem that caused militarism and terrorism in the area. This is in clear contravention of the African Charter on the rights of all member states to good environment. Article 24 of the African Charter provides that, "All peoples shall have the right to a general satisfactory environment favourable to their development". The Nigerian state and oil companies collectively infringed on the rights to 'favourable environment' of the Delta communities through oil pollution and gas flaring in the area. This seriously abridged the happiness and traditional occupations of the Niger Delta people in addition to health problems it has caused. It was to this effect that the youth rose in challenge to the oil companies and the Nigerian government, forming as it were, militant groups that posed dangerous threats to oil exploration activities. The militants also engaged in kidnapping oil workers for ransom in addition to other criminal activities. Government response to youth militia and attacks on oil installations has been the use of military violence to clamp down on the insurgents. This negates the rights of the Delta inhabitants and poses threats to peace in the region.

\footnotetext{
77 Niger Delta Interview conducted by the author, August 2013.

${ }^{78}$ Cited from Human Rights Watch, interview, July 7, 1997, The Price of Oil <http://www.hrw.org/reports/1999/ nigew991-05.htm>.

${ }^{79}$ HRW, The Price of Oil http://www.hrw.org/reports/1999/nigeria/Ngew991-05.htm

80 Ibid.

${ }^{81}$ HRW, 'The Price of Oil: Corporate Responsibility and Human Rights Violations in Nigeria's Oil Producing Communities' (1997) 11(3) PIRC Intelligence. Principle 11 of the 1992 UN Rio Declaration on Environment and Development states that 'Environmental standards, management objectives and priorities should reflect the environmental context to which they apply. Standards applied by some countries may be inappropriate and of unwarranted economic social cost to other countries, in particular developing countries.' As noted above, however, Nigerian law at many points explicitly refers to international standards and requires companies operating in Nigeria to respect those standards.

82 Ken Saro-Wiwa, "“My Story," text of statement to the Civil Disturbances Tribunal', reprinted in Ogoni: Trials and Travails (Lagos: Civil Liberties Organisation, 1996) 42-3.
} 
The UNDP ${ }^{83} 2006$ report summed up the effects of environmental pollution in the Niger Delta thus:

The world is concerned about the destruction of aquatic animals, fishing and farming activities, impairment of human health, loss of biodiversity in breeding grounds, loss of portable drinking water all of which combined to result in poverty, rural underdevelopment and bitterness in the Niger Delta.

The United Nations Environment Programme (UNEP) ${ }^{84}$ on the invitation of the Nigerian government in 2010 has assessed the environmental damage in the Niger Delta. UNEP indicted the oil companies and Nigerian government for environmental disaster in the Delta region. It stated that it could take 30 years to clean up the Delta environment and could cost $\$ 30$ billion.

The Niger Delta agitation for better environment only end up in clampdowns, into long years of detention and highhandedness from Nigerian state and oil companies in the region. This has been the basis upon which the Niger Delta conflict is anchored. Hence, the reign of terror and abuses in the region.

\section{The rise of militarism and terrorism in the Niger Delta}

The efforts of the Delta people to attract government attention to their plights through petitions from local communities and peaceful demonstrations by old and young, including women and children failed to yield positive results. ${ }^{85}$ Added to this, eight leaders of the Niger Delta, including Ken Saro-Wiwa, a notable environmentalist and activist were, in November 1995, arrested and hanged by the military government of Nigeria for demonstrating after an oil spillage in the Niger Delta. ${ }^{86}$

The failure of government attention to the demands of the Delta people led to the rise of insurgent and terrorist groups in the region. ${ }^{87}$ These groups, such as Movement for the Survival of the Ogoni People (MOSOP), Ijaw Youth Council (IYC), Movement for the Emancipation of the Niger Delta (MEND), Niger Delta Peoples Volunteer Force (NDPVF), amongst others, emerged and began to challenge government forces sent to protect oil facilities in the Delta in gun battles over the ownership and control of oil resources in the region. Their activities included kidnapping of oil workers for ransom, blowing up oil-pipelines, crude oil bunkering and stealing, and general disruption of oil exploration activities in the Niger Delta - all geared at drawing government attention to the plight of the people. Because of money made from kidnapping and oil bunkering, criminality and other social crimes have increased so that the situation is now difficult for Government to control.

\section{Recommendations}

This paper suggests that the Nigerian state and oil companies in the Niger Delta should put in place a fair and transparent compensation mechanism and reparation system for the people of the Delta. Government and oil companies should respect the rights of all people living within the Niger Delta and implement, in totality, the recommendations of the African Commission on Human and People's Rights to ownership of property (ACHPR). ${ }^{88}$ Oil companies should be compelled by law to disclose information on the impacts of oil operations on the environment and human rights in non-technical language.

Besides, oil companies should be made, by law, to follow the guidelines governing mining and exploration of natural resources the world over, and adhere to its rules and regulations to ensure environmental justice in the Niger Delta. This will also regulate the oil companies into adopting public health and environmental laws, regulations and policies that reduce the disparity in the exposure to pollution, which focus on programs that address the physical environment. Companies that flout these rules should be made to face the wrath of the law. In this way, oil pollution in the Delta would be minimised. The UN should also compel the

\footnotetext{
${ }^{83}$ UNDP, ‘Niger Delta Development Report’ (Abuja Nigeria, 2006).

${ }^{84}$ See for details, UNEP, 2011 <http://www.unep.org>.

${ }^{85}$ Beanu, above $\mathrm{n} 5$.

86 Ibid

87 Ibid

${ }^{88}$ The right to property shall be guaranteed. It may only be encroached upon in the interest of public need or in the general interest of the community and in accordance with the provisions of appropriate laws.
} 
Nigerian government and the oil companies to implement the UNEP ${ }^{89}$ findings and recommendations on the environmental pollutions of the Niger Delta.

Youth empowerment should be undertaken by the Federal Government, state governments of the Delta region and the oil companies as a means of thwarting youth insurgency and militancy in the area. The Government should engage all stakeholders in the Delta in dialogue rather than through military force.

\section{Conclusion}

The contemporary discourse in Nigeria's political history is the resource war in the Niger Delta. To talk about fiscal economy in Nigeria is to talk about crude oil and the allocation of revenue accruing from it. Oil discovery in Nigeria in 1956 was supposed to be a blessing to Nigerians, but it has turned out to be an object of war and struggle between classes, factions and groups acting through state structures and ethnic identity. Since oil is power and power is oil in the context of the Nigeria's political economy, the struggle for it becomes the primary object of politics. The Nigerian government has introduced laws that deprive communities who own the land upon which oil is extracted from benefiting from oil revenues. The inequitable distribution of oil wealth exacerbates inequalities in Nigerian societies and has stimulated considerable conflict, leading to gruesome killings by Nigerian soldiers and police - whose weapons have been bought by oil wealth that should have been shared with the people they repress. Until the Government engages in meaningful dialogue with aggrieved communities, the unrest in the Niger Delta is likely to continue.

\footnotetext{
${ }^{89}$ For decades, oil extraction in the Niger Delta has led to wide-scale contamination of the environment. To address the problem, the Nigerian state invited UNEP to conduct an independent assessment of the environmental and public health impacts of oil pollution in Ogoniland deemed as the most strongly affected part of the Niger Delta. The UNEP in its recommendations indicted the oil companies and Nigerian government for long years of oil pollution in the region. Full text of the recommendations can be gleaned here: <http://www.unep.org/newscentre/default.aspx?> $<$ www.unep.org/nigeria>.
} 